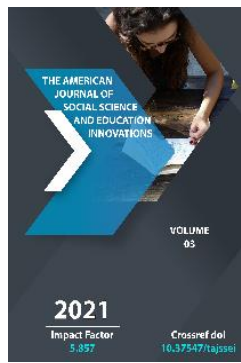

\title{
Historical Geography Of Kitab’s Principality
}

\author{
Bakhrom Djalolovich Karimov \\ Lecturer, Karshi State University, Uzbekistan
}

Journal Website:

http://usajournalshub.c

om/index,php/tajssei

Copyright: Original content from this work may be used under the terms of the creative commons attributes 4.0 licence.

\section{ABSTRACT}

The Kashkadarya oasis is was important part of the Bukhara Emirate, and the cities of the oasis played an important role in the socio-political, economic and cultural life of the emirate. One of such important areas is the last medieval Kitab principality, which is covered in this article about its historical-geography, history, socio-economic and political history, on the basis of scientific sources and memoirs and diaries of Russian tourists.

\section{KEYWORDS}

Kifti-ab, palace, registan, tower, Sagdiana, stream of Kashaf, Kitab’s fortress, Orda, neighbourhood, kenagas.

\section{INTRODUCTION}

Present-day region of Kashkadarya of Uzbekistan occupies a fertile agricultural area of the ancient Sogd oasis and is located in the heart of Movarounnahr, between the Zarafshan and Kashkadarya rivers, which in ancient times flowed into the Amu Darya. All 
stages of historical development of our country are closely connected with this region and its cities. In particular, among the cities of the Kashkadarya oasis in the late Middle Ages, the city of Kitab, located on the upper reaches of the Kashkadarya, on its left bank, is one of such important cities.

The city of Kitab is one of the youngest cities of our country. Kifti-Ob means or a city between two rivers. The territory of Kitab district is surrounded on three sides by high mountains Ziyovuddin, Qurghonteppa (continuation of Zarafshan mountain range) and TakhtaKaracha (continuation of Gissar mountain range). Geographically, the city is bordered on the north by Samarkand region, on the east by the neighboring Republic of Tajikistan, on the south by Shakhrisabz, on the west by Chirakchi districts. Two rivers, the Kashkadarya and the Akdarya, flow on both sides of the city.

If we take a look at the history of this city, we can see that it has existed since time immemorial. According to sources, in ancient and early medieval times, the center of the Kesh oasis was located on the site of the city of Kitab.

\section{THE MAIN FINDINGS AND RESULTS}

Traces of the ancient city in this area date back to antiquity. About 2,000 years ago, a large city with a fortified arch (citadel) with an area of 40 hectares appeared here. The Ark is a fortress in the center of the city; in ancient times the ruler of the city.In written sources it is mentioned by the names of kohandiz, koh, castle.It was built on a natural ridge or a specially designed high platform, surrounded by a solid wall, with one or two gates. There are the houses of kings and emirs, officials and generals, a administration, a mint and a dungeon inside the arch. In the early Middle Ages, the city was called Kesh and for some time became the capital of Sogdiana.

As Colonel Belyavsky crossed the Takhtakoracha Pass from Samarkand, he notes that the beginning of a wide, flat valley with the principalities of Kitab, Shakhrisabz, Yakkabog, and Chirakchi, which were 40 versts from northeast to southwest and 25 versts perpendicularly, more than 1,000 square versts of fertile land. Captain Pokotilo discovered that the city of Kitab was 2,150 feet, $703 \mathrm{~mm}$ above sea level.

In the 18th century, the Kitab Fortress was built on the site of the first medieval city ruins. As a result of the large influx of settlers around it, a new city was founded and the city gradually developed. Kashkadarya, an important water source of the oasis, supplied water to 600,000 desiatins of Kitab, Shahrisabz, Yakkabag, Chirakchi, Guzar and Karshi principalities. The lands totaled 79,988 tanobs in the Kitab principality.

On the threshold of the Kitab Walls, Kashkadarya flowed rapidly through a rockfilled valley as a mountain-like river.

According to historians, there are the following ideas about the meaning of the term "Kitab". A group of researchers connects the name of the city with the name of the Kashaf valley in the upper reaches of the Kashkadarya.

Another group says that the Tajik word "kift" is derived from the word "kiftob", which means "shoulder", and "ob" is water, meaning "city by the water". Other researchers have suggested that it is derived from the Sogdian word kat, which means place, and the Tajik word ob, 
which means water, meaning "city by the water."

It is known that in the first half of the XVIII century in the eastern part of the Kashkadarya oasis there were fortresses such as Sangfurush, Ulash, Kitab, and later only the Kitab fortress developed and, unlike other fortresses, rose to the level of the city.

According to historical sources, the city had six gates and they were interconnected through the city streets. The northern gate is named after Samarkand, the eastern gate after Kunchikar, the southern gate after Sharbatkhana, the south-western gate after Khoja Rushnoi, the western gate after Govkhona, and the north-western gate under Darvazai Charmgar.According to researchers, the city gates were in good condition until the end of the XIX and the beginning of the XX century.

Located in the center of the city, nobleman's the hexagonal tower stretches 2,000 meters from west to east and 750 meters from north to south. The town area is surrounded by a mud wall with a total length of 4600 meters. Thickness of the wall, was 5-5.5 meters, 2 meters at the top, and 8 feet high, that is, about 7 meters. Tto the northwest of the fort is a mosque, and in front of it is Registan Square, and from here the roads from the city center to the gates begin. The city's main market is adjacent to Registan Square.

It's not necessary to describe the city. From the Syrdarya to the Hindu Kush, from the Mediterranean to the walls of China, all Asian cities have the same pattern formed over the centuries. Only we focused on the small markets we encountered at every step.
Extremely narrow, roundabouts led to the Horde, where the Beck and the Kitab Administration were located. The horde was built at a height not as great as in other Asian cities. The square in front of the Orda Gate (Registan) is crowded on Sundays. Vendors of fruit and anything else can sit there and trade.

Kitab is not much different from other cities in Central Asia. Twisted streets, cotton houses, the same canals of water, and those people. The streets, especially as I walked through the bazaar, were greeted by everyone standing up and greeting me with gestures, which was not only out of respect, but also sincerely.

From this it can be said that these data were given by the above-mentioned Russian tourist N. This confirms Maev's statement.

In the 19th century, Russian travellers wrote that the city had 3 madrasas, several Friday mosques, 3 caravanserais, 1 bathhouse, and many bazaars.

At the end of the XIX - beginning of the XX century the number of caravanserais was found to be six. They are all located around the baazar.

Researchers from NUU (National Univeristy of Uzbekistan) have identified 82 guzar names in the city, 11 of which are second names of guzars, and the number of guzars is 71 . In the Kitab, each guzar had its own mosque. These are: Ayronchi, Arabkhona, Baland Masjid, Beklik Mosque, Govxona, JuxutoDegrez, Donglik, Duradgorlik, Dusvoy, EttiUylik I, EttiUylik II, Yorogamil, Zargar, Ipakchilik, Eshonguzar, Kabrohun, Qazikhana, Karapoychalik, Karapoycha, Qorasuv , Small jewelry, Small leather, Kokand fortress, Kotarma, Qushariq, Sword mill, Lulixona, 
Laklakon, Minglar, Mirzaboy, Mulladarvesh, Miltiqsozlik, Naqshin masjid, Poholguzar, Agalik, Ravotaq, Sarbozon, Rahdon, Rahdon mosque, RegdonSurumcha, TagiQala, Taqchi, Tashkozi, Tegirmonboshi, HalfaShakar, Xonaqo, Khoja Sattor, Khoja Bukhari,Khoja Rushnoi, Chalpak mosque, Khoja village, Chakpidozlik, Leather, Chinarlik, Chitchilik, Chukurchashma, Shavvat, Shodmonkhoja, Shaykhon, Shakoulik, Shaqi, Shohkoprik, Shatut and so on.

As can be seen from the names of the guzars mentioned above, most of them reflect the lifestyle of the people of the city of Kitab and the main occupation they are engaged in. In particular, the name of the guzar was identified in a total of 22 related to 3 trades, 19 types of handicrafts. Craftsmanship guzars take into account the natural conditions necessary for a particular type of craft in a particular part of the city, in some cases. For example, butchers, tanners yarn, and related professions that generally need to use large amounts of water are located in the military part of the city, i.e., in the wet part where there are streams and springs.

Russian researchers have differing opinions about the population of the Kitab principality and the city, and there are some differences in their data. According to A.Kun, the population of the principality of Kitab is 35,000, and the population of the city is 18,500 . R. Kanopka has a population of 15,000, E.C. Skyler 15 thousand, V. I. Masalskiy, Yu. A. The Sukharevas put the number at about 30,000. Based on these data, the population of the city can be estimated at the end of the XVIII - mid XIX centuries, around 15-18 thousand people. According to the sources and historical topographic observations, the total population of the Duchy was about 30-35 thousand people.

In 1960, a study conducted by ATEK to study the historical topography of the city of Kitab revealed that life in many guzars came to an end by the end of the 19th century. Including, A. The Guzars of Govkhana, Dusvoy, Minglar, Khoja Rushnoi, Chitgar, Ettiuylik, and Sharbatkhana were abandoned in the late 19th and early 2oth centuries, and some of them were replaced by public buildings.

Although the origin of the book is associated with the activities of the principalities of the Kenagas tribe and these descendants, the Tajiks also played an important role in the formation of the city.

In the city of Kitab, as in other cities of the oasis, weaving, embroidery, pottery, tanning, blacksmithing, degreasing, glassmaking and other handicrafts flourished.

In the fields of Kitab principality mainly four varieties of wheat, barley, rice, oats, corn (in small quantities), cotton, millet, sesame, kunach (millet), flax, lentils, beans, alfalfa, mosh, peppers (peas), tobacco (kallachi and surramak varieties), poppy, onion, beet, kadi (squash), cabbage, cucumber, tarrak (long cucumber), turnips, peppers, carrots, melons, watermelons planted are. They are from the beginning of the month of spring, that is, from the 15th day of the month of Hamal, to the 15th day of the month of Sawr; winter wheat and barley are sown from the criterion month. According to Bobobek and Jorabek, the beys of Kitab and Shakhrisabz, wheat and barley account for $3 / 10$ of the total arable land, rice for $4 / 10$ and other crops for the remaining 3/10. Depending on the time of sowing, the above 
crops are divided into two types: white (which includes wheat, barley, lentils, flax, moss and peas) and blue (which includes other crops). After the land was harvested twice a year and white crops were harvested, blue crops were planted in its place. According to Russian sources, the Kitab is surrounded by lush gardens and the Kitob's peaches was popular in the Bukhara Emirate.

The types of wood used in construction included poplar, willow, and elm. The abundance of mulberry trees laid the foundation for the development of silkworm breeding.

Although the fields and flora of Kitab mountains to the city of the Kitab do not attract much attention, the road from Kitab to Shakhrisabz gives a completely different picture. This place is truly the pearl of Central Asia, a fertile and prosperous valley.

Here you can find hundred-year-old mulberry trees with horns on all sides.

Due to its high productivity and rich water resources, most of the agricultural products grown in the Shakhrisabz, Kitab and Yakkabag economic districts were exported to other principalities for sale.

At the beginning of the XIX-XX centuries the basis of economic life of Kitab principality was agriculture and animal husbandry. During the study period, the mountainous and foothill areas of the principality were specialized in animal husbandry, dry farming, horticulture, and the foothills were settled agriculture, which produced a large number of agricultural products.

\section{CONCLUSION}

Today, the approach to the study of history has reached a new level. One of the most important issues was the study of the history of the oases and cities of the country, the study of archeology. The Kesh oasis, one of the most important oases in Central Asia, has a long history. By the Early Iron Age, the eastern part of the Kashkadarya oasis - the ancient Kitab Shahrisabz, Yakkabag - began to be rapidly developed.

The research of such researchers as V.V.Bartold, V.L.Viyatkin, B.Denike, A.Yu.Yakubovsky, B.N.Zasipkin, Ya.G.Gulamov, T.M.Mirgiyosov, S.K.Kabanov, S.A.Sudakov, V.L.Varonina, G.N.Gachanov, M.E.Masson, G.A.Pugachenkova, O.A.Sukhareva played an important role in the detailed coverage of the history of the late Middle Ages in the Kesh oasis, in particular, the city of Kitab.

Large-scale archeological expeditions were carried out. Another such expedition is the archeological-topographic expedition ATEK Kesh (Kashkadarya) by M.E. Masson in 1963. As a result of such expeditions, many archeological complexes in the ancient Kesh oasis, in particular, the historical and geographical, socio-economic and political life of the city and the principality of the Book were discovered and analyzed.

In general, during the Bukhara Emirate, the Kitab principality and adjacent estates were among the main economic centers of the Kashkadarya oasis. The area consisted of a fortress, a citadel, and a rabad surrounded by a defensive wall. In addition to the beck fortress, the cities are home to a number of public and religious worship facilities, including mosques, 
markets, shops, baths, caravanserais, and more. In such cities of the Kashkadarya oasis, as well as in Bukhara and Samarkand, there are several dozen handicraft guzars, where the majority of the city's population lived. The main source of income for the people of the city is agriculture, animal husbandry and trade, which is also explained by the fact that it is the economic backbone of the oasis and is located in a convenient geographical area.

\section{REFERENCES}

1. AstanovaG.Yu. Documentary sources of the Bukhara Khanate of the 19th and early 20th centuries, about administrative divisions and their sizes // Late feudal city of Central Asia. Actual problems of the historical. science. - Tashkent: Fan, 1990

2. A.Hasanov. Urban planning and architecture of Kashkadarya oasis (XVI-XIX centuries) "Voris" 2019

3. Kabanov S. K. Archaeological explorations in Shakhrisyabzskom oasis // Izvestiya AN UzSSR. -Tashkent: 1951. - Vyp.№ 6.

4. Cap. Pokotilo. Report on a trip to Central and Eastern Bukhara in 1886. - Tashkent: Printing House of the District Headquarters, 1888.

5. Krashennikova N.I. The past of Kitaba // Collection: Milestones of the times.-T: G. Gulyam, 1989.

6. Kuhn A. Essays on the Shakhrisab Bekstvo // ZIRGO by dep. geography. - Vsh. Vi. SPb., 1880

7. Logofet D.I. Buxarskoe khanate under the Russian protectorate. - SPb .: B.I., 1911.

8. Logofet D. Through Bukhara. Travel sketches in Central Asia // Turkestan collection. - Tashkent, 1907.

9. Maev N. Essays on the Bukhara Khanate // Yearbook. - SPb. 1879. no. V.
10. N.A. Maev. Essays of the Bukhara Khanate. T; "Science and Development" 2012

11. Masson E.M. Works of the Kesh archaeological and topographic expedition of the Tashkent State University ... // Collection of scientific works of Tashkent State University. - Tashkent, 1977.-Issue. 533.

12. Nabiev A. Historical local lore (main sources of studying the country). Tashkent "Teacher" 1996.

13. SagdullaevA.S. From the history of ancient Kesha. -T: G.Gulyama, 1989.

14. Sagdullaev A.S. and others. Excerpts from the history of ancient Kesh-Shakhrisabz.-T : 1998 .

15. Semyonov-Tyan-Shanskiy V.P. Russia. Full geographic description. Turkestan area. SPb .: Izd-voA.F.Devriena, 1913. - T. XIX.

16. Yu.Skayler. Bukhara (continued) History of Uzbekistan. Scientific journal. Science Publishing House 2015 y-5 bet

17. Col. Belyavsky. Description of the doomed section, which contains the traversed paths within the Shaar-Sabiz, Guzar bekstvo and part of the upland Derbent uplands // Collection of geographical, topographic and statistical materials on Asia. - SPb .: Military Printing House, 1894. Issue. LVII. .

18. Choriev A, Hamroev T.Kesh in sources // Shakhrisabz city in world history place.Tashkent, 2002 